\title{
Offenders in the post-industrial labour market: lubricating the revolving door?
}

\author{
Del Roy Fletcher* \\ Sheffield Hallam University
}

\begin{abstract}
UK policy makers are increasingly seeking to improve the skills of offenders as a means of reducing re-offending. However, the past forty years have witnessed profound changes in the nature of work. Yet there has been little research which has explored their experiences in the post-industrial labour market and the consequences for re-offending. This article begins to address this gap in our knowledge. It draws upon a series of in-depth interviews with offenders undertaken by the author as part of the evaluation of a prison-based vocational training project. A key conclusion which emerges is that many offenders have been consigned to the margins of the labour force and spend much of their working lives in the informal labour market. This may have profound consequences for re-offending.
\end{abstract}

Keywords: offenders, labour market, re-offending, informal work, skills.

\section{Introduction}

The prison population in England and Wales has risen by over 50 percent in the last decade and stands at record levels. Many prisoners appear to be caught in a revolving door, 67 percent are reconvicted within two years of their release (Home Office, 2005). High levels of re-offending carry a high social and financial cost. In terms of the latter, the Social Exclusion Unit (2002) has estimated that the cost of recorded crime committed by ex-prisoners is $£ 11$ billion per year.

It is against this background that UK policy makers have increasingly sought to improve the skills of offenders as a means of reducing re-offending. This is being translated into the development of new programmes and the allocation of increased funding for prison-based learning and skills provision. This process has culminated in the December 2005 Green Paper, Reducing Re-offending through Skills and Employment. In May 2007 it was announced that the West Midland, and East of England will become test bed regions to help take forward the UK Government's proposals to improve offender skills. 
The past forty years have witnessed profound changes in the nature of work. Yet there has been little research which has explored the experiences of offenders in the post-industrial labour market and the consequences for re-offending. This article seeks to begin to address this gap in our knowledge. It draws upon a series of in-depth interviews with offenders undertaken by the author as part of the evaluation of a prison-based vocational training project. The paper identifies the position of offenders in the post-industrial labour market and discusses the impact of recent welfare reform. It considers how they have responded to deindustrialisation and the growth of 'interactive service work'. It draws on a range of literature to explore the extent to which offenders are able to reconstruct their identities to exploit the growth of service sector employment. In particular, the concept of 'protest masculinity' developed by Connell (1995) is utilised to discuss the way in which offenders relate to the postindustrial labour market.

A series of in-depth interviews was undertaken with offenders as part of the evaluation of a vocational training project at HMP Lindholme. The latter is a Category $\mathrm{C}$ prison located near Doncaster in South Yorkshire. Interviews were scheduled to take place in the final week of imprisonment and individuals were then tracked and interviewed at the three month post-release stage. The former were conducted face-toface and sought to collect a range of trainee data; detail their involvement with the project; and explore the preparations that had been made for their release. The evaluators also made use of the Local Inmate Data System (LIDS) to gain individual offending data. The post-release interviews investigated the present circumstances of former trainees, jobsearch and contact with organisations providing help with accessing accommodation and work.

Seven pre-release and five post-release interviews were conducted between July 2005 and July 2006. All interviewees were white and aged between twenty three and forty years. They were serving custodial sentences ranging from two to four years for main offences that included burglary (three individuals), supply of drugs, conspiracy to supply drugs, possession with intent and attempted robbery. Those interviewed had between seven and twenty three previous convictions, many drug-related, and up to eight custodial sentences.

Drawing upon the HMP Lindholme interviews it is proposed that the labour market position of male ex-prisoners is structured by three key factors. First, the changing nature of the work in the post-industrial labour market. Second, the role of employment in the construction of masculine identities. Finally, the reform of welfare to emphasise work. These three factors are examined in turn, after a short review of current UK policy in this particular field.

A key finding is that offenders are unable to reconstruct their identities and continue to seek male-dominated, low-skilled manual work. Consequently, many have been consigned to the margins of the labour force and spend much of their working lives in the informal labour market. The collapse of the stable employment around which traditional models of masculinity were organised has also changed the way in which many relate to the labour market. Connell's (1995) concept of 'protest masculinity' is helpful in characterising the nature of these changes. The marginal position of most offenders in the labour market may have profound social consequences. The indications are that some are caught in a cycle of short-term informal work interspersed with spells of criminal activity and imprisonment. 


\section{The policy context}

The growing interest of UK policy makers with improving the skills and employment prospects of offenders has taken place against a background of an overcrowded prison system and rising reconviction rates. The Social Exclusion Unit (2002) Reducing reoffending by ex-prisoners report acknowledged that prison sentences were not turning the majority of individuals away from crime. It went on to argue that high levels of reoffending carry a high financial and social cost. Employment was identified as one of the nine key factors that influence re-offending.

The report suggested that employment could reduce re-offending by between a third and a half. Yet it noted that two thirds of prisoners enter custody having spent much of their life outside stable work. The Social Exclusion Unit concluded that drug, alcohol and mental health problems all played a part, as did coming from deprived neighbourhoods where formal employment opportunities are limited. The Unit went on to argue that low skills feed into low employability, with only half of prisoners having the reading skills, one-fifth the writing skills and less than one-third the numeracy necessary for 96 per cent of all jobs.

The focus on skills was further developed by the December 2005 Green Paper, Reducing Re-Offending Through Skills and Employment, which confirmed that "an important strand of the strategy to reduce re-offending is concerted action to transform the skills and employment prospects of offenders' (HM Government, 2005: 11). The report acknowledged that the multiple needs of many offenders can make them extremely hard to help. However, success could have 'a positive impact on the incidence of re-offending, to the benefit of individuals, their families and communities, and wider society' (HM Government 2005: 12).

Reducing Re-offending through Skills and Employment: Next Steps was published in December 2006 following a period of consultation. Two test bed regions in the West Midlands and East of England will be established in September 2007 to take forward the Government's proposals for improving offender skills. Three key themes are emerging:

- a strong drive to engage employers through a Reducing Re-Offending Corporate Alliance

- building on the new offender learning and skills service

- developing the new emphasis on skills and jobs in prison and probation.

\section{The changing nature of work}

De-industrialisation and the growing service intensity of the economy have had a profound effect on the nature of work. Every developed country has seen changes in the amount and type of employment: notably the rise in badly paid work, in part-time and flexible employment (voluntary and involuntary), and in the growth of the informal economy (Gans, 1996). While de-industrialisation has led to the decline of maledominated semi-skilled and unskilled employment in the manufacturing and extractive industries, the growth of service sector work has been associated with the growing 'feminisation' of the labour force. Bauman (2005) views this as part of a wider transformation from a society of producers to a society of consumers.

The shift to a service dominated economy has generated new forms of employmentcentred poverty. Sassen (1996) has, for example, shown that it has polarised labour markets between 'knowledge and information intensive' and 'labour intense and low 
productivity' sectors. Lash and Urry (1994) argue that the British economy has been a prodigious creator of 'junk jobs' in occupations such as cleaning, fast food and bar work. These jobs are highly routinised and subject to surveillance where employees often have to learn and repeat standardised scripts in their interaction with customers. They argue that 'junk jobs' only become economically viable when the low wages associated with them are supplemented by benefits.

It is low-level service jobs that increasingly present the most accessible route into work for groups such as offenders. Yet the skills and aptitudes required are fundamentally different to those demanded for manufacturing employment. Hogarth and Wilson (2001) have found that the demand for physical and technical skills has been superseded by the requirement for interpersonal and customer handling skills. This is because the service sector involves the exchange of intangibles such as information rather than material artefacts and is dependant upon a direct social relationship between the producer and consumer of the service (McDowell, 2003). 'Interactive service work' which involves face-to-face or voice-to-voice contact makes use of the worker's looks, personalities and emotions as well as their physical and intellectual capacities. Consequently, the embodied performance is effectively part of the 'product' which is 'sold' to the customer (Lash \& Urry, 1994).

The present research finds that male ex-prisoners appear to have been consigned to the margins of the labour force with many spending the majority of their working lives in the informal labour market. This was so routine that prisoners at HMP Lindholme often failed to make a distinction between formal and informal work. Careful questioning revealed that three had no experience in the formal labour market but had a succession of 'cash-in-hand' jobs secured through friends and acquaintances. The work histories of the remainder comprised mainly informal work. A thirty five year old had, for example, worked as a painter and decorator and joiner on building sites. However, he ruefully noted: 'But not proper jobs on building sites. Employers want three years minimum experience and a good CV'. Another had spent ten years in the building trades but mostly undertaking 'cash-in-hand' work.

It appears that the growth of subcontracting, particularly in construction, has provided offenders with rich opportunities to engage in informal work. From the employers' perspective informal labour may help to cut labour costs and bolster competitiveness. It may also provide the ultimate flexible labour force with employers having no obligations to workers other than paying them. The growing use of subcontractors has also underpinned the growth of informal recruitment. It is against this background that Sassen (1996) suggests that economic restructuring has led to a shift of labour market functions such as recruitment to the household or community. All of those interviewed consulted family, friends and acquaintances in order to find work. Most were returning to the same town or city which facilitated this reliance on local social networks. A twenty five year old was, for instance, able to secure some short-term plastering work from an uncle. Most had also made direct contact with employers. For example, a thirty five year old had personally approached site supervisors on twelve major building sites in Leeds.

Employer discrimination may also help to consign ex-prisoners to the informal labour market. Fletcher's (2003) review of previous research that has explored how employers respond to job applications from offenders has highlighted several key messages:

- most private sector employers lack the appropriate policy frameworks for dealing with the issues raised by the recruitment of offenders in a responsible way. Equal opportunities policies, for example, are not seen as being directly relevant and few have policies that specifically mention offenders 
p. 84. Offenders in the post-industrial labour market: lubricating the revolving door?

- most seek criminal record information from job applicants

- the type of offence is a key consideration with violent and sexual crimes often being viewed as most serious

- many recruitment exercises are staffed by line managers who are unfamiliar with the legislative framework and have not received appropriate information or training to deal with the issue. In such circumstances anxiety on the part of the recruiter that offenders cannot be trusted can be a significant factor hampering their recruitment

- very few knowingly recruit offenders.

A thirty nine year old reported that his most important obstacle was: 'The usual one -my record'. A thirty five year old declared that: 'If employers have got the pick of the bunch I won't get it'. Only one individual identified a lack of job opportunities. It became clear in the course of the discussions that many were confident that they could access informal work but some recognised its limitations. A twenty three year old declared that: 'I can get a job easy but I don't want dead-end labouring jobs'. Three individuals indicated that a lack of relevant work experience prevented them from gaining 'proper' jobs.

\section{Work and identity}

Waged work has traditionally been seen as a core element in the construction of masculine identities. Willis (1977) has, for example, linked working class masculinity to shop floor culture and the wage form. It is, however, clear that large numbers of working class youth are now growing up without any expectation of the stable employment around which familiar models of working class masculinity were organised. Theories of reflexive modernity (Giddens, 1991; Beck, 1992) suggest that individuals are able to reflexively reconstruct their identities in line with changing requirements. Notions of increased agency in the reconstitution of their lives and growing abilities to construct a career based on reflexive choice may have little relevance for those with few skills and inappropriate social capital.

Nixon's (2006) study of unemployed men in Manchester found that they were not reconstructing their identities but were continuing to seek male-dominated, low-skilled manual jobs. He concluded that customer service jobs 'required the young men to deny themselves, to be passive and socially acceptable, to cover up their class and background, their feelings and emotions, their accents, their behaviour' (Nixon, 2006: 214). A study of Manhattan youth undertaken by Bourgois (1995) has shown how the attitudes and behaviour inculcated by generations of blue-collar fathers were now counter-productive. In particular, a tough machismo that was valued in the local community had become a barrier to gaining employment. Those recruited to service sector jobs quickly lost their positions because their social and cultural capital was inappropriate to the workplace. 'Their inter-personal social skills are even more inadequate than their limited professional capacities. They do not know how to look at their fellow service workers- let alone their supervisors- without intimidating them' (Bourgois, 1995: 142-3).

Connell (1995) has developed the concept of 'protest masculinity' to characterise the way in which economically marginal young men relate to the labour market. Violence, school resistance, crime, heavy drug/alcohol use, and occasional manual labour were found to be markers of 'protest masculinity'. Connell's work has the virtue of recognising that the masculinity of those facing intermittent employment and 
p. 85. Offenders in the post-industrial labour market: lubricating the revolving door?

economic marginality is not shaped by a specific workplace but in relation to the labour market as a whole. From the employers perspective such individuals are interchangeable with any other worker. Work is often alienating and consequently from the individual's perspective any job is interchangeable with another. It is in this context that the young men exhibited a 'radical pragmatism' in their approach to earning a living which extends to crime and involves mobilising their personal links. "Almost every work history in the group shows the importance of personal links, especially family links, in negotiating the labour market' (Connell, 1995: 97).

The parallels with the lives of the prisoners interviewed at HMP Lindholme are striking. All of those interviewed had drug problems prior to custody and some were former drug dealers. A thirty nine year old confided that: 'All I knew before [participating in the vocational training project] was how to sell drugs'. At least three were former heroin addicts and several were being prescribed replacement medication during their incarceration. Drug taking often extended to family and friends. The girlfriend of a twenty five year old heroin addict was, for example, also a user. A thirty five year old with twenty three previous convictions including major drug offences explained that all his friends were users. Perhaps even more surprising was that two appeared to be under the influence of drugs during the pre-release interview.

It was, therefore, puzzling that very few expressed concerns about relapsing into drug use on their release. A thirty five year old was an exception. He explained that: ' $I$ will know at least six people [drug dealers] from stepping off the train'. He went on to note that: 'People find it hard to stay off [drugs] - all my mates are on it. What do you do write off all your mates?' Nevertheless, the post-release interviews revealed that several had become re-immersed in the local drugs subculture. One individual was, for example, initially well motivated to find work but subsequent rejection in the formal labour market had coincided with his relapse into heroin use. At the time of interview he was missing appointments with his probation officer. Similarly, one of the exprisoners declining a post-release interview had relapsed. His probation officer confided that: 'He's not doing too well at the moment'. The author was unable to establish contact with another individual, a former drug dealer.

Similarly, most employment histories were characterised by cycles of short-term work interspersed with spells of economic inactivity and imprisonment. Nevertheless, all had worked prior to incarceration albeit in male-dominated low-skilled manual jobs such as labouring, erecting scaffolding, gardening, warehousing, roofing, carpet laying, joinery, painting and decorating, and excavating ground works. None had any experience of service work or had any intention of seeking it. Four of those interviewed were former labourers, three had experience as painters and decorators, two had been employed in warehouses and two had undertaken gardening work. A few listed four or more types of employment. One individual had, for example, been a roofer, window fitter, painter and decorator, carpet layer and had excavated ground works.

A reluctance to appear weak was also a feature of the 'protest masculinity' identified by Connell (1995) and was evident in the HMP Lindholme interviews. The author sought, for example, to explore any concerns that offenders might have had about their release. Most indicated that they had none whatsoever. One identified potential difficulties finding appropriate work. However, no-one mentioned problems with finding suitable accommodation or re-establishing personal relationships. More surprising still was the fact that just one individual voiced concern about relapsing into drug misuse. The perceived need to appear to be in control was exemplified by a twenty five year old who reported that his only concern was with finding a supportive employer. Further enquiries revealed that he was on methadone, has a partner that is a crack addict and who was contesting the custody of their very young child. 
p. 86. Offenders in the post-industrial labour market: lubricating the revolving door?

\section{Welfare reform}

UK policy makers have increasingly endorsed a 'workfare' agenda in relation to labour market policy which has drawn heavily on US experience. The American workfare model emphasises individual responsibility in the quest for self-dependency rather than income maintenance. Welfare dependency and passivity are seen as a primary cause of worklessness which necessitates a compulsive strategy to enforce work habits. In the UK benefit recipients have increasingly been required to attend compulsory workfocussed interviews as a condition of benefit receipt. Similarly, the establishment of Jobcentre Plus can be seen as an attempt to move away from the notion of benefit eligibility towards a culture of personalised assistance with job search (Daguerre and Taylor-Gooby, 2004).

Daguerre and Taylor-Gooby (2004) argue that, although the British welfare state still provides a more robust safety net and the degree of compulsion is less pronounced than the US, both regimes place a strong emphasis on the work ethic and citizenship rights are made conditional on a willingness to participate in paid work. Smith and Macnicol (2001) maintain that such reforms seek to expand the labour supply to meet the requirements of the precarious and casualised end of the labour market. It is in this context that Smith (2005: 111) concludes that: "the lives of the unemployed are sandwiched between low-paid irregular employment on the one hand, and institutions that are regarded as coercive adversaries on the other'. Wacquant (1999) views this as a 'new penal common sense' which seeks to criminalise poverty and normalise insecure, low-paid employment.

Most interviewees reported that they had not contacted any organisation to help them find work or training in the three month period following their release. One individual had been in touch with Connexions and the Society of Voluntary Associates (SOVA) and another had apparently discussed employment with his probation officer. Some hostility was expressed towards Jobcentre Plus which appeared to stem from the perceived focus on policing benefit entitlement and the low paid nature of the work advertised in Jobcentres. Just two individuals reported that they were still visiting the Jobcentre three months later. All the indications are that this was an infrequent and largely symbolic activity. Many also fell back on their own resources to find somewhere to live. A twenty three year old triumphantly claimed that he had contacted: 'None whatsoever'. He was found to be living in a caravan that had been procured by his mother. Another individual had spent several months sleeping on the floors of friends and acquaintances.

The unwillingness of many ex-prisoners to engage with the welfare system may stem from several factors. At the outset, it must be recognised that those with drug and alcohol problems are difficult to reach because of their limited contact with statutory agencies. Second, Connell (1995) has shown that many offenders define their masculinity against forms of authority. Fletcher (2004) has, for example, found that many are attracted to self-employment precisely because it offers freedom from supervision. Third, welfare reform has resulted in greater levels of surveillance of the activities of those claiming work-related benefits. This is a very unpalatable prospect for many of those deprived of their liberty especially given the low benefit levels. Fourth, many participated in local social networks to get work. Finally, cash-in-hand work may offer the prospect of higher incomes than those typically advertised in Jobcentres. A thirty five year old pointed out that he could earn $£ 90$ per day laying cables. 
p. 87. Offenders in the post-industrial labour market: lubricating the revolving door?

\section{Conclusions}

Economic restructuring raises important questions about the ability of the postindustrial labour market to generate employment opportunities that are both accessible and capable of providing a vehicle for the social inclusion of offenders. The research on prisoners in HMP Lindholme has found that many spend their working lives in the informal economy undertaking both illegal (criminal) and otherwise legal (but undeclared) activity. In terms of the latter, short spells of informal work especially in the construction sector and the domestic household market were a key feature of the work histories of all interviewees. This may have profound social consequences because the link between employment and offending is strongest for those in stable, well paid employment with prospects (see Farrington et al., 1986).

Previous research has identified a strong link between economic marginality and informal activity. Leonard's (1998) research in Belfast found that 49 per cent of unemployed men and 27 per cent of economically inactive women interviewed on the Newbury estate had some type of informal work. Smith (2005) also discovered widespread participation in undeclared employment amongst residents of the St Helier estate in London. MacDonald's (1994) study of benefit fraud ('fiddly jobs') in Cleveland has underlined the importance of social networks in determining access to such opportunities. He concluded that those "who did not live a public life on the streets and in the pubs of particular estates, but instead lived a life of isolation, boredom and home centred day-to-day tedium became excluded from avenues into fiddly work' (MacDonald, 1994: 525).

The prisoner interviews have suggested that informal work may also have a number of attractions for those with a criminal record. First, the growth of subcontracting has meant that it has been readily available to those with the right contacts even in communities characterised by high levels of worklessness. Second, it can bypass the discrimination that many face in the formal labour market. Third, it facilitates minimal contact with the statutory agencies. Several interviewees had financial responsibilities for young children and were keen not to attract the attention of the Child Support Agency. Fourth, the irregular nature of informal work can be more easily accommodated within the lifestyles of those with drink and / or drug problems. Finally, the nature of the work does not require offenders to reconstruct their identities.

The severe difficulties faced by offenders in the formal labour market have not been brought about by a progressive failure to assimilate the work ethic. Welfare dependency and passivity were not major features of the lives of those interviewed at HMP Lindholme. There was also little evidence that individuals had a lower cultural commitment to work. The collapse of the stable employment around which traditional models of masculinity were organised has, however, changed the way in which many relate to the labour market. Connell's (1995) concept of 'protest masculinity' is helpful in characterising the nature of these changes. Welfare reform may have further pushed groups like offenders towards the margins of society. All of this underlines the entrenched nature of the problem and the consequent need for policy makers to take a long-term, joined-up approach. Many would argue that prison overcrowding is, for example, incompatible with this task. In the longer-term the challenge for policy makers is to reduce the gap between the aspirations of offenders and what they are able to achieve in the post-industrial labour market. 
p. 88. Offenders in the post-industrial labour market: lubricating the revolving door?

\section{Acknowledgements}

This paper draws upon a research study funded by Yorkshire Forward. The author would like to acknowledge the advice and assistance of Debbie Crellin, the Research Manager who oversaw the study from commissioning to conclusion.

* Correspondence Address: Del Roy Fletcher, Centre for Regional Economic and Social Research, Sheffield Hallam University, Unit 10, Science Park, Howard Street, S1 1WB, UK. Email: d.r.fletcher@shu.ac.uk.

\section{References}

Auletta, K. (1982) The Underclass. New York: Random House.

Baumann, Z. (2005) Work, consumerism and the new poor. Maidenhead: Open University Press.

Beck, U. (1992) The risk society. London: Sage.

Bourgois, P. (1995) In Search of Respect: Selling Crack in El Barrio. Cambridge: Cambridge University Press.

Connell, R. W. (1995) Masculinities. Oxford: Polity Press.

Dean, H. and Taylor-Gooby, P. (1992) Dependency culture. The explosion of a myth. London: Harvester Wheatsheaf.

Daguerre, A. and Taylor-Gooby, P. (2004) Neglecting Europe: explaining the predominance of American ideas in New Labour's welfare policies since 1997. Journal of European Social Policy, 14, 1, 25-39.

Farrington, D et al. (1986) Unemployment, school leaving and crime. British Journal of Criminology, 25, 335-56.

Fletcher, D. (2003) Employers, recruitment and offenders: underlining the limits of work-focused welfare? Policy \& Politics, 31, 4, 497-510.

Fletcher, D. (2004) Reducing Re-offending: The Enterprise Option. Sheffield: Small Business Service. Available at: www.sbs.gov.uk/research/

Fletcher, D. (2006) Review and evaluation of Yorkshire Forward's Construction Training in Prisons Project at HMP Lindholme. Interim Report.

Fletcher, D., Taylor, A., Breeze, I. and Hughes, S. (2001) Recruiting and employing offenders. Work \& Opportunity Series No. 27. York: Joseph Rowntree Foundation.

Gans, H. (1996) From underclass to undercaste: Some observations about the future of the post-industrial economy and its major victims, in: Mingione, E (Editor) Urban Poverty and the Underclass. Oxford: Blackwell.

Giddens, A. (1991) Modernity and self-identity: self and society in the late modern age. Cambridge: Polity Press.

Grover, C. (2003) New Labour, welfare reform and the reserve army of labour. Capital \& Class, 79, 17-23.

H. M. Government. (2005) Reducing Re-Offending Through Skills and Employment. Cm 6702. London.

Hochschild, A. (1983) The managed heart: the commercialisation of human feeling. Berkeley: University of California Press.

Hogarth, T. and Wilson, B. (2001) Employers skill survey: skills, local areas and unemployment. London: DfEE.

Home Office (2005) Re-offending of adults: results from the 2002 cohort. London: Home Office.

Lash, S. \& Urry J. (1994) Economies of Signs and Space. London: Sage. 
p. 89. Offenders in the post-industrial labour market: lubricating the revolving door?

Leonard, M. (1998) The long-term unemployed, informal economic activity and the 'underclass' in Belfast: Rejecting or reinstating the work ethic. International Journal of Urban and Regional Research, 22, 1, 42-59.

MacDonald, R. (1994) Fiddly jobs, undeclared working and the something for nothing society, Work, Employment \& Society, 8, 4, 507-530.

McDowell, L. (2003) Redundant masculinities? Employment change and white working class youth. Oxford: Blackwell.

Murray, C.A. (1990) (Editor) The emerging British underclass. London: Institute of Economic Affairs.

Myrdal, G. (1962) Challenge to affluence. New York: Pantheon.

Nixon, D. (2006) 'I just like working with my hands': employment aspirations and the meaning of work for low-skilled unemployed men in Britain's service economy. Journal of Education and Work, 19, 2, 201-217.

Prison Reform Trust (2006) Bromley Briefings. Prison Factfile. April 2006.

Sassen, S. (1996) Service employment regimes and the new inequality, in: Mingione E. (Editor) Urban Poverty and the Underclass. Oxford: Blackwell.

Smith, D. M (2005) On the margins of inclusion. Changing labour markets and social exclusion in London. Bristol: Policy Press.

Social Exclusion Unit (2002) Reducing re-offending by ex-prisoners. London: Office of the Deputy Prime Minister.

Tyler, M. \& Taylor, S. (1998) The exchange of aesthetics: women's work and 'the gift'. Gender, Work and Organisation, 5, 3, 165-171.

Walkowitz, C. (2002) The social relations of body work. Work, Employment and Society, 16, 497-510.

Walters, W. (2000) Unemployment and Government: Genealogies of the Social. Cambridge: Cambridge University Press.

Willis, P. (1977) Learning to labour. How working class kids get working class jobs. London: Hutchinson. 